\title{
Effects of organic mulching on soil aggregate stability and aggregate binding agents in an urban forest in Beijing, China
}

\author{
Wei Zhou ${ }^{1} \cdot$ Xiangyang Sun ${ }^{1} \cdot \operatorname{Suyan} \mathrm{Li}^{1} \cdot$ \\ Tiantian Du $^{1} \cdot$ Yi Zheng ${ }^{1} \cdot$ Zhihui Fan $^{1}$
}

Received: 4 April 2021 / Accepted: 14 July 2021 / Published online: 19 October 2021

(C) The Author(s) 2021

\begin{abstract}
Urban forest soil is often disturbed by rapid urbanization. Organic mulching is effective for improving soil quality and aggregate stability. This study evaluated how soil binding agents changed aggregate stability through organic mulching in urban forest soils. Three treatments were applied in Jiufeng National Forest Park, Beijing: (1) no organic mulch (control); (2) wood chips alone (5 cm thickness); and, (3) wood chips + wood compost (This mulch was divided into two layers, the upper layer of wood chips $(2.5 \mathrm{~cm})$, the lower layer wood compost $(2.5 \mathrm{~cm}))$. Soil samples were collected from the surface $10-\mathrm{cm}$ soil layer and fraction into four aggregates. Glomalin-related soil protein and soil organic carbon were measured in bulk soil and the four aggregates. The results show that wood chips + wood compost increased the proportion of large and small macroaggregates, mean weight diameter and geometric mean diameter. The total and easily extractable glomalinrelated soil protein were higher in the wood chips + wood compost. However, soil organic carbon was lower in the wood chips alone application compared to the controls and wood chips + wood compost. Easily extractable / total glomalin-related soil protein and glomalin-related soil protein / soil organic carbon ratios of wood chips alone and wood
\end{abstract}

Project funding This project was supported financially by the Natural Science Foundation of Beijing Municipality (Grant number 6202021).

The online version is available at http://www.springerlink.com.

Corresponding editor: Zhu Hong.

Xiangyang Sun

sunxybjfusoil@163.com

1 College of Forestry, Beijing Forestry University, Beijing 100083, People's Republic of China chips + wood compost had increased trend compared to the controls but did not reach significant levels $(p>0.05)$. Mean weight diameter and geometric mean diameter correlated positively with total and easily extractable glomalin-related soil protein but were not positively correlated with soil organic carbon, the ratios of easily extractable and total glomalin-related soil protein, and the ratios of glomalin-related soil protein and soil organic carbon. Redundancy analysis revealed that total glomalin-related soil protein was the most important driver for soil aggregate stability, especially the total glomalin-related soil protein of small macroaggregates. The results suggest that wood chips + wood compost enhanced soil aggregate stability through the increase of glomalin-related soil protein. Wood chips alone cannot enhance soil aggregate stability in urban forests in the short term.

Keywords Organic mulching · Soil aggregate stability · Soil binding agents $\cdot$ Glomalin-related soil protein (GRSP) · Soil organic carbon (SOC)

\section{Introduction}

Urban forest soils have important ecological and social functions in improving the quality of the urban environment (Yang et al. 2005; Wang et al. 2019a). Because of intensive human activities, urban forest soils are more vulnerable than natural forest soils and have unique physicochemical properties (Zhou et al. 2017, 2018). The characteristics of urban forest soils, including compaction, low-nutrient levels, poor structure, and decreased aggregate stability have been reported in numerous studies (Wang et al. 2014a; Sax et al. 2017; Kranz et al. 2020). These characteristics affect the sustainable supply of soil ecosystem services, and therefore 
measures are needed to support the sustainable development of urban forests (Sax et al. 2017).

As the basic unit of structure, aggregates affect soil quality and stability (Ma et al. 2020). Soil aggregates maintain and supply organic carbon (SOC) and nutrients, impacting biogeochemical reactions (Wei et al. 2020). Numerous studies have shown that glomalin-related soil protein (GRSP) and soil organic carbon (SOC) are the most important binding agents that accelerate aggregate formation (Zhang et al. 2012; Chen et al. 2019; Jing et al. 2021). Furthermore, GRSP produced by arbuscular mycorrhizal fungi bind soil particles to form aggregates and improve aggregate stability (Xie et al. 2015; Wang et al. 2019b; Xiao et al. 2019). The decomposition of SOC (especially available SOC), accelerates microbial activity and is associated with macroaggregate formation (Andruschkewitsch et al. 2014). The increase in GRSP and SOC increases microbial biomass and activity and consequently a higher rate of macro-aggregate formation to improve aggregate stability (Liu et al. 2014).

The re-utilization of urban green waste can resolve environmental problems and promote sustainable development (Qu et al. 2019) because returning green waste to urban soils will improve structure and function (Kranz et al. 2020; Somerville et al. 2020). Organic mulches (wood chips, wood compost) produced from green waste have been widely used in urban soil landscaping and environmental improvement (Zhang et al. 2017; Qu et al. 2019). In addition, studies have reported that the application of green waste is significant for improving physicochemical properties because the surface layer is more receptive to the direct input of fresh organic matter (Wang et al. 2019c; Zhong et al. 2019; Kranz et al. 2020; Sun et al. 2021). Organic mulches applied to disturbed or degraded urban soils benefit soil structure, i.e., microbial activities can be stimulated to generate more binding agents to improve soil aggregation and enhance organic levels (Kranz et al. 2020). However, there are few assessments on the effects of soil aggregate stability under organic mulches, especially in urban forest soils. Therefore, studies on the role of organic mulches in urban forest soils should will facilitate the prediction of long-term effects on soil quality and aggregate stability (Fungo et al. 2017).

In northern China, the withering of herbaceous plants in winter results in large areas of bare land, often leading to dust and air pollution (Zhang et al. 2017). Many cities promote organic mulch application in winter to address this problem. As spring progresses, the mulches are removed and ornamental plants grown for landscaping urban spaces. However, studies on the effect of short-term organic mulching on urban soil structure and aggregate stability are relatively limited (Fungo et al. 2017). Mulching with wood chips was the most common way to beautify the environment (Sun et al. 2021). However, composts cannot be used alone because of their characteristics (low weight and black color) (Sax et al. 2017; Kranz et al. 2020) but it is feasible to cover urban soils with wood chips or wood chips mixed with wood composts (Qu et al. 2019). The characteristics of wood chips were large particle size, high lignin content and slow decomposition rate, while wood compost was the opposite. The best way to enhance soil aggregate stability should be chosen for mulching in the short term.

Although the correlation between soil aggregate stability and aggregate binding agents (GRSP, SOC) has been shown in many studies, the mechanism of aggregation requires further study (Zhang et al. 2014; Fungo et al. 2017). This research will evaluate the short term effects of organic mulching on soil aggregate stability in the urban forest and determine how soil binding agents change aggregate stability. It was hypothesized that: (1) organic mulching would increase soil aggregation by increasing the GRSP and SOC contents in bulk soil and in each aggregate fraction; (2) wood chips + wood compost would be more effective in improving soil structure than wood chips alone; and, (3) GRSP and SOC would contribute differently to the soil aggregate stability in the short term.

\section{Materials and methods}

\section{Study site}

The experimental site was located in the Jiufeng National Forest Park $\left(40^{\circ} 4^{\prime} 10^{\prime \prime} \mathrm{N}, 116^{\circ} 6^{\prime} 25^{\prime \prime} \mathrm{E}\right)$, Haidian District, Beijing, China. It is characterized by a sub-humid continental climate with cold, dry winters and hot, rainy summers. The average rainfall is $630 \mathrm{~mm}$ and the average annual temperature is $12.5^{\circ} \mathrm{C}$. Rainfall mainly occurs from June to September. Pinus tabulaeformis Carr. and Platycladus orientalis (L.) Franco are the main tree species.

\section{Experimental design and soil sampling}

In this study, the experimental plots were set out in July 2018 and undisturbed soil samples collected from the topsoil (upper $10 \mathrm{~cm}$ ) in November 2020. Three treatments were included: (1) no application of organic mulch (CK); (2) $5-\mathrm{cm}$ layer of wood chips alone (W); and, (3) 5-cm layer of wood chips + wood compost (W\&C). This mulch was divided into two layers, the upper layer of wood chips $(2.5 \mathrm{~cm})$, the lower layer wood compost $(2.5 \mathrm{~cm})$. The experimental plots were arranged in a completely randomized design with three replications. The particle sizes of wood chips and wood compost were approximately 5 and $0.2 \mathrm{~cm}$, respectively, and both material of the main tree species (i.e., Sophora japonica, Populus tomentosa, Fraxinus chinensis Roxb.).

Three $5 \times 5 \mathrm{~m}$ plots were randomly set out for each treatment, and soil was collected from three randomly located soil 
pits and mixed to form a bulk sample for each plot. Visible debris was removed and the samples were air-dried at room temperature to determine soil aggregate stability. In addition, a total of nine soil samples and 36 soil aggregate samples were collected for SOC and GRSP determination in the bulk soil and in each aggregate fraction. The basic properties of organic mulches and soil prior to mulching are presented in Table 1.

\section{Soil aggregate stability analysis}

The aggregate size distribution in the soil samples was determined by wet sieving. The $50 \mathrm{~g}$ air-dried bulk sample was immersed in deionized water on a set of sieves with $2,0.25$, and $0.053 \mathrm{~mm}$ meshes. The sieves were shaken up and down $3 \mathrm{~cm}$ for 25 times/min for aggregate separation. After sieving, the samples were oven dried at $60^{\circ} \mathrm{C}$ for $24 \mathrm{~h}$, weighed, the mass distribution of aggregate sizes calculated, and the samples were kept for further chemical analysis. Four aggregate size fractions were obtained: large macroaggregates $(>2 \mathrm{~mm})$, small macroaggregates $(2-0.25 \mathrm{~mm})$, microaggregates $(0.25-0.053 \mathrm{~mm})$, and silt + clay fractions $(<0.053 \mathrm{~mm})$ (Modak et al. 2020).

The soil aggregate stability index was determined using the mean weight diameter (MWD) and the geometric mean diameter (GMD) according to Ma et al. 2020. The proportion of soil aggregate distribution $\left(w_{i}\right)$, MWD, and GMD were calculated using the following equations:

$w_{\mathrm{i}}=\frac{m_{\mathrm{i}}}{m} \times 100 \%$

$M_{\mathrm{WD}}=\sum_{i=1}^{n} x_{\mathrm{i}} w_{\mathrm{i}}$

$G_{\mathrm{MD}}=\exp \left(\sum_{i=1}^{n} w_{\mathrm{i}} \ln x_{\mathrm{i}}\right)$

where, $M_{\mathrm{WD}}$ is the mean weight diameter; $G_{\mathrm{MD}}$ is the geometric mean diameter; $w_{\mathrm{i}}$ is the proportion of soil aggregates in the corresponding size fraction $(\%) ; m_{\mathrm{i}}$ is the mass of the corresponding size fraction $(\mathrm{g}) ; m$ is the total mass of the air-dried bulk soil samples $(\mathrm{g}) ; n$ is the number of size fractions; and $\bar{x}_{\mathrm{i}}$ is the average particle size of two adjacent sieve grades $(\mathrm{mm})$.

\section{Determination of SOC and GRSP contents}

SOC contents in bulk soils and the different aggregates were determined with the $\mathrm{K}_{2} \mathrm{Cr}_{2} \mathrm{O}_{7}$ volumetric method (Bao 2000). GRSP was divided into two pools, i.e. easily extractable GRSP (EG) and total GRSP (TG). EG and TG were extracted from the samples and their quantities were determined following Wright et al. (1998) with minor modifications. EG was extracted by immersing a $0.5 \mathrm{~g}$ sample in $8 \mathrm{ml}$ of $20 \mathrm{mM}$ sodium citrate ( $\mathrm{pH} 7.0)$ and autoclaved at $121^{\circ} \mathrm{C}$ for $30 \mathrm{~min}$. TG was extracted by immersing a $0.1 \mathrm{~g}$ sample in $8 \mathrm{ml}$ of $50 \mathrm{mM}$ sodium citrate (pH 8.0) and autoclaved at $121^{\circ} \mathrm{C}$ for $60 \mathrm{~min}$. The supernatants were separated by centrifugation at $6000 \mathrm{rpm}$ for $6 \mathrm{~min}$ and collected. In order to detect complete TG contents, three cycles of extraction and centrifugation were carried out. The typical reddish-brown GRSP color had disappeared and the supernatant was clear. All TG supernatants from each sample were combined and the protein contents determined using a Bradford-Lowry assay with bovine serum albumin as the standard (Wang et al. 2018; Xiao et al. 2019).

\section{Statistical analysis}

All data were tested for normal distribution using Shapiro-Wilk, and homogeneity of variance using Levene's test. A one-way analysis of variance (ANOVA) and Duncan multiple comparison test $(P<0.05)$ were used to assess the effects of mulch treatments in bulk soils and in each aggregate fraction on the measured parameters. Data in the tables are mean \pm standard deviation (SD). The main influencing factors for the soil aggregate stability index (MWD and GMD) were evaluated by Pearson correlation, redundancy analysis (RDA), variation partitioning, and conditional term effect. Statistical analyses used Excel 2019, SPSS 22.0, and Canoco v. 5.0.2.
Table 1 Soil and organic mulch basic properties prior to mulching

\begin{tabular}{llllllll}
\hline Variables & $\mathrm{BD}\left(\mathrm{g} / \mathrm{cm}^{3}\right)$ & $\mathrm{pH}$ & $\mathrm{EC}(\mathrm{mS} / \mathrm{cm})$ & $\mathrm{SOC}(\mathrm{g} / \mathrm{kg})$ & $\mathrm{TN}(\mathrm{g} / \mathrm{kg})$ & $\mathrm{AP}(\mathrm{mg} / \mathrm{kg})$ & $\mathrm{AK}(\mathrm{mg} / \mathrm{kg})$ \\
\hline Soil & 1.36 & 7.5 & 0.1 & 11.5 & 1.2 & 3.0 & 222.0 \\
Wood chips & nd & 6.4 & 1.2 & 492.5 & 11.8 & nd & nd \\
Woody composts & nd & 8.2 & 1.6 & 341.3 & 23.2 & nd & nd \\
\hline
\end{tabular}

BD is soil bulk density; EC is electrical conductivity; SOC is soil organic carbon; TN is total nitrogen; AP is available phosphorus; $\mathrm{AK}$ is available potassium; nd is not determined 


\section{Results}

\section{Effects of organic mulching on aggregate distribution and stability}

As shown in Table 2, the proportional distribution of aggregates showed that small macroaggregates $(2-0.25 \mathrm{~mm})$ comprised the largest proportion of the soil, significantly higher than other aggregates under the same treatments $(P<0.05$, except for the controls). Large ( $(2 \mathrm{~mm})$ and small macroaggregates accounted for $51-67 \%$ of the total aggregates. The proportion of large macroaggregates was significantly higher, and microaggregates $(0.25-0.053 \mathrm{~mm})$ were markedly lower under wood chips + wood compost than in the controls and wood chips $(P<0.05)$. The proportion of small macroaggregate and silt + clay fractions $(<0.053 \mathrm{~mm})$ was insignificant in the different treatments $(p>0.05)$. Wood chips + wood compost significantly increased mean weight diameter and geometric mean diameter compared to the controls and wood chips $(P<0.05)$, while wood chips did not change the mean weight diameter and geometric mean diameter compared to the controls. The mean weight diameter and geometric mean diameter of different treatments were wood chips + wood compost $>$ wood chips $=$ controls .

\section{Effect of different treatments on glomalin-related soil protein in bulk soil and in different aggregates}

The easily extractable GRSP and total GRSP contents of wood chips + wood compost in the bulk soil were higher than wood chips and the controls (Table 3). These decreased as wood chips + wood compost $>$ controls $>$ wood chips, similar to the trends in soil organic carbon. The total GRSP of the wood chips + wood compost treatments increased by 27.9 and $47.6 \%$ in the bulk soil compared with the controls and wood chips, respectively. The easily extractable GRSP of the wood chips + wood compost treatments increased by 27.9 and $33.7 \%$ in the bulk soil compared with the controls and wood chips, respectively.

The total GRSP (TG) and easily extractable GRSP (EG) levels in each fraction were similar to those in the bulk soil, in descending order as wood chips + wood compost $>$ the controls $>$ wood chips, with wood chips + wood compost significantly greater. The change in easily extractable GRSP contents in each fraction was similar to changes in the total GRSP but only microaggregates and silt + clay fractions of wood chips + wood compost were significantly greater than in other treatments (Fig. 1a, b).

\section{Effect of different treatments on the soil organic carbon in bulk soil and in different aggregates}

The application of wood chips did not significantly increase the soil organic carbon in bulk soil. Compared to the wood chips, the soil organic carbon of wood chips + wood compost and the controls in the bulk soil increased dramatically by 52.2 and $49.1 \%$, respectively (Table 3 ). soil organic carbon levels in each fraction were similar to that of the bulk soil, in large macroaggregates and microaggregates in a descending order as wood chips + wood compost $>$ controls $>$ wood chips, and in small macroaggregates and silt + clay fractions with a descending order as controls $>$ wood chips + wood
Table 2 Soil aggregate distribution, mean weight diameter and geometric mean diameter under different treatments
Table 3 Glomalin-related soil protein and soil organic carbon contents in bulk soil and the ratios of EG/TG, TG/SOC, EG/ SOC under different treatments

\begin{tabular}{lllllll}
\hline Treatment & \multicolumn{2}{l}{ Soil aggregate distribution (\%) } & MWD (mm) & GMD (mm) \\
\cline { 2 - 5 } & $>2 \mathrm{~mm}$ & $2-0.25 \mathrm{~mm}$ & $0.25-0.053 \mathrm{~mm}$ & $<0.053 \mathrm{~mm}$ & & \\
\hline W & $14.0 \pm 0.03^{\mathrm{Bb}}$ & $38.7 \pm 0.06^{\mathrm{Aa}}$ & $31.7 \pm 0.01^{\mathrm{Aab}}$ & $15.6 \pm 0.04^{\mathrm{Ba}}$ & $0.6 \pm 0.04^{\mathrm{b}}$ & $0.4 \pm 0.05^{\mathrm{b}}$ \\
W\&C & $26.4 \pm 0.05^{\mathrm{Ba}}$ & $41.2 \pm 0.03^{\mathrm{Aa}}$ & $21.4 \pm 0.04^{\mathrm{Bb}}$ & $11.1 \pm 0.02^{\mathrm{Ca}}$ & $0.8 \pm 0.05^{\mathrm{a}}$ & $0.6 \pm 0.09^{\mathrm{a}}$ \\
$\mathrm{CK}$ & $18.7 \pm 0.07^{\mathrm{BCb}}$ & $31.8 \pm 0.03^{\mathrm{ABa}}$ & $34.5 \pm 0.07^{\mathrm{Aa}}$ & $15.0 \pm 0.03^{\mathrm{Ca}}$ & $0.6 \pm 0.06^{\mathrm{b}}$ & $0.4 \pm 0.07^{\mathrm{b}}$ \\
\hline
\end{tabular}

$\mathrm{W}$ is wood chips alone; $\mathrm{W} \& \mathrm{C}$ is wood chips + woody compost; CK is control; MWD is mean weight diameter; GMD is geometric mean diameter; lowercase letters indicate significant differences $(P<0.05)$ among the different treatments, uppercase letters indicate significant differences $(P<0.05)$ among the different sized aggregates under the same treatment

\begin{tabular}{lllllll}
\hline Treatment & EG $(\mathrm{g} / \mathrm{kg})$ & TG $(\mathrm{g} / \mathrm{kg})$ & SOC $(\mathrm{g} / \mathrm{kg})$ & EG/TG & TG/SOC & EG/SOC \\
\hline W & $1.1 \pm 0.1^{\mathrm{b}}$ & $3.3 \pm 0.6^{\mathrm{b}}$ & $9.3 \pm 0.8^{\mathrm{b}}$ & $0.35 \pm 0.04^{\mathrm{a}}$ & $0.35 \pm 0.03^{\mathrm{a}}$ & $0.12 \pm 0.01^{\mathrm{a}}$ \\
W\&C & $1.7 \pm 0.1^{\mathrm{a}}$ & $6.3 \pm 0.5^{\mathrm{a}}$ & $19.5 \pm 2.4^{\mathrm{a}}$ & $0.27 \pm 0.04^{\mathrm{a}}$ & $0.32 \pm 0.03^{\mathrm{a}}$ & $0.09 \pm 0.02^{\mathrm{b}}$ \\
CK & $1.2 \pm 0.1^{\mathrm{b}}$ & $4.5 \pm 0.4^{\mathrm{b}}$ & $18.3 \pm 0.4^{\mathrm{a}}$ & $0.27 \pm 0.01^{\mathrm{a}}$ & $0.25 \pm 0.03^{\mathrm{b}}$ & $0.07 \pm 0.01^{\mathrm{b}}$ \\
\hline
\end{tabular}

$\mathrm{W}$ is wood chips alone; W\&C is wood chips + woody compost; CK is control; EG is easily extractable glomalin-related soil protein; TG is total glomalin-related soil protein; SOC is soil organic carbon; lowercase letters indicate significant differences $(P<0.05)$ among the different treatments, uppercase letters indicate significant differences $(P<0.05)$ among the different sized aggregates under the same treatment 
$\square$ wood chips $\quad \square$ wood chips + wood compost $\quad \square$ controls
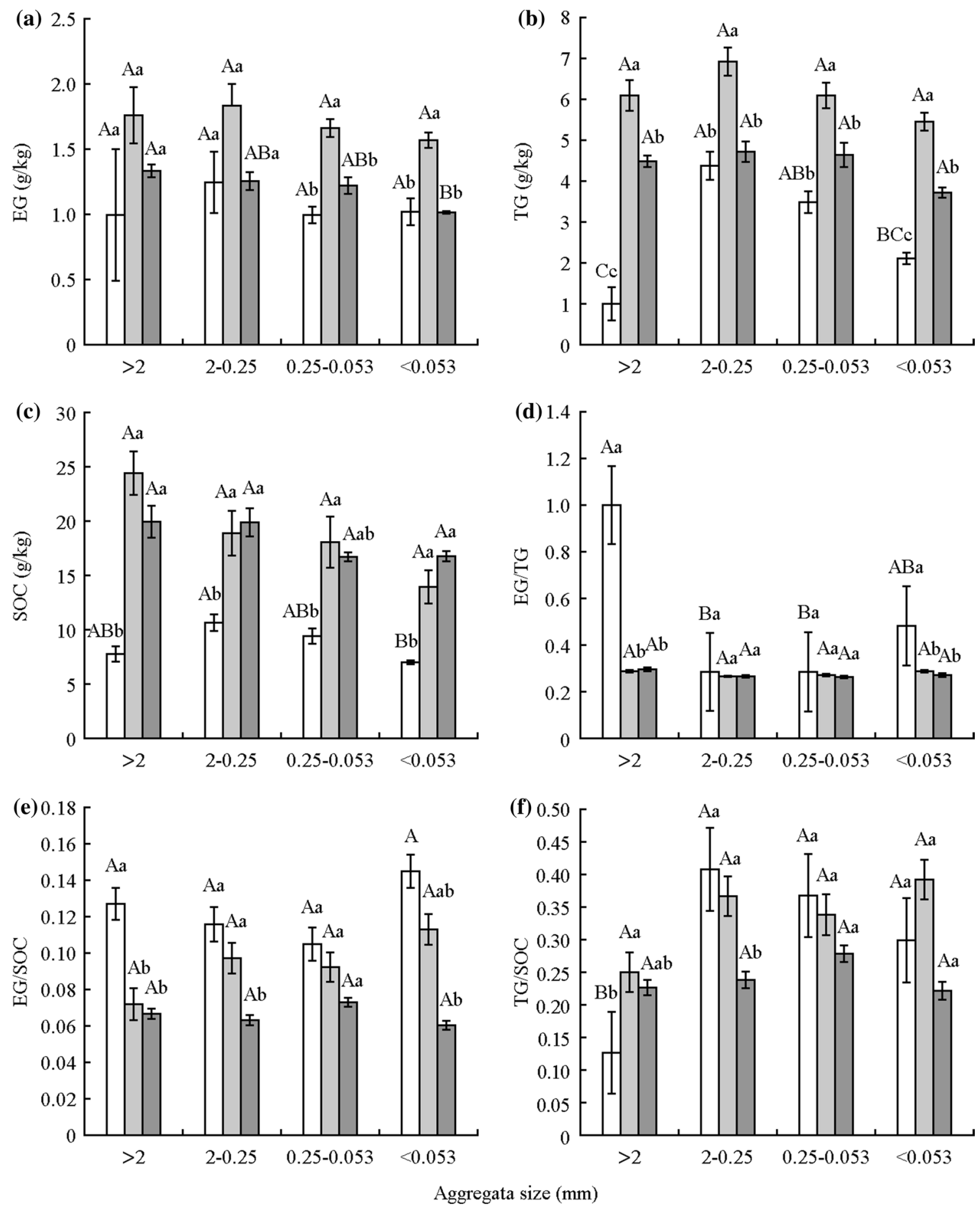

Fig. 1 Easily extractable glomalin-related soil protein, total glomalin-related soil protein, and soil organic carbon contents in different soil aggregates under different treatments. Bars indicate standard deviation. EG is easily extractable glomalin-related soil protein; TG is total glomalin-related soil protein; SOC is soil organic carbon.
Lowercase letters indicate significant differences $(P<0.05)$ among the different treatments, uppercase letters indicate significant differences $(P<0.05)$ among the different sized aggregates under the same treatments 
compost $>$ wood chips. Wood chips + wood compost and the controls showed no significant difference in each fraction but were significantly higher than wood chips (Fig. 1c).

\section{Effect of different treatments on EG/TG, EG/SOC, and TG/SOC ratios in bulk soil and in the different aggregates}

EG/TG, EG/SOC, and TG/SOC ratios were calculated for the bulk soil (Table 3) and for the different soil aggregates (Fig. $1 \mathrm{~d}, \mathrm{e}, \mathrm{f}$ ).

In the bulk soil, easily extractable GRSP (EG) contribution to soil organic carbon (SOC) sequestration was $7-12 \%$, and the total GRSP (TG) contribution was $25-35 \%$. Wood chips led to higher ratios of EG/TG and TG/SOC. The TG/ SOC ratio was significantly higher than the controls. The EG/SOC ratio was considerably higher than the controls and the wood chips + wood compost. The differences in the EG/ TG ratios were not significant.

For the different aggregates, EG/TG ratio of wood chips in large macroaggregates and silt + clay fractions was significantly higher than for wood chips + wood compost and controls $(P<0.05)$. EG/SOC ratios in all fractions had a descending order as wood chips $>$ wood chips + wood compost $>$ controls, wood chips were significantly higher than the controls $(P<0.05$, except microaggregates). TG/SOC of wood chips + wood compost was higher than the controls in different aggregates, but only in large and small macroaggregates.

\section{Effect of different aggregates on the GRSP, SOC, and the EG/TG, EG/SOC and TG/SOC ratios under the same treatments}

As shown in Fig. 1. The easily extractable GRSP levels of large and small macroaggregates were slightly higher than for other aggregates but not statistically significant except for the controls. Total GRSP and soil organic carbon levels were similar to the easily extractable GRSP except for wood chips. The contents of large and small macroaggregates were slightly higher than for the microaggregate and silt + clay fractions, also not statistically significant. As for EG/TG, EG/SOC, and TG/SOC ratios, except for EG/TG and EG/ SOC ratios under wood chips, the difference in aggregates under the same treatment were not significant.

\section{Relationships among soil aggregate stability and binding agents}

The relationship between soil aggregate stability index and aggregate binding agents (glomalin-related soil protein and soil organic carbon) in the bulk soil and for the different aggregates was determined by Pearson correlation tests.
Table 4 Correlation between glomalin-related soil protein, soil organic carbon and aggregate stability

\begin{tabular}{|c|c|c|c|}
\hline Index & Soil aggregates & MWD & GMD \\
\hline \multirow[t]{5}{*}{ EG } & Bulk soil & $0.719^{*}$ & $0.744 *$ \\
\hline & $>2$ & 0.479 & 0.477 \\
\hline & $2-0.25$ & $0.718^{*}$ & $0.715^{*}$ \\
\hline & $0.25-0.053$ & 0.634 & 0.66 \\
\hline & $<0.053$ & $0.822 * *$ & $0.863 * *$ \\
\hline \multirow[t]{5}{*}{ TG } & Bulk soil & $0.742 *$ & $0.814 * *$ \\
\hline & $>2$ & 0.591 & $0.697 *$ \\
\hline & $2-0.25$ & $0.834 * *$ & $0.879 * *$ \\
\hline & $0.25-0.053$ & 0.658 & $0.731 *$ \\
\hline & $<0.053$ & $0.686^{*}$ & $0.771 *$ \\
\hline \multirow[t]{5}{*}{ SOC } & Bulk soil & 0.416 & 0.502 \\
\hline & $>2$ & 0.514 & 0.549 \\
\hline & $2-0.25$ & 0.129 & 0.225 \\
\hline & $0.25-0.053$ & 0.532 & 0.665 \\
\hline & $<0.053$ & 0.029 & 0.111 \\
\hline \multirow[t]{5}{*}{ EG/TG } & Bulk soil & -0.424 & -0.537 \\
\hline & $>2$ & -0.247 & -0.379 \\
\hline & $2-0.25$ & 0.018 & -0.057 \\
\hline & $0.25-0.053$ & -0.123 & -0.247 \\
\hline & $<0.053$ & -0.236 & -0.340 \\
\hline \multirow[t]{5}{*}{ EG/SOC } & Bulk soil & -0.053 & -0.155 \\
\hline & $>2$ & 0.067 & 0.008 \\
\hline & $2-0.25$ & 0.366 & 0.264 \\
\hline & $0.25-0.053$ & -0.015 & -0.150 \\
\hline & $<0.053$ & 0.336 & 0.295 \\
\hline \multirow[t]{5}{*}{ TG/SOC } & Bulk soil & 0.358 & 0.302 \\
\hline & $>2$ & 0.406 & 0.553 \\
\hline & $2-0.25$ & 0.481 & 0.401 \\
\hline & $0.25-0.053$ & 0.059 & -0.029 \\
\hline & $<0.053$ & $0.729 *$ & $0.767 *$ \\
\hline
\end{tabular}

*Indicates $P<0.05$; ** indicates $P<0.01$

Table 4 shows that the contents of total and easily extractable GRSP in bulk soil, macroaggregates, and in silt + clay fractions were significantly $(P<0.05)$ or highly significantly $(P<0.01)$ correlated with mean weight diameter and geometric mean diameter. Among soil organic carbon, TG/EG, EG/SOC, and TG/SOC (except for silt + clay fractions) in the bulk soil and different aggregates, there was no correlation with mean weight diameter or geometric mean diameter. Furthermore, soil organic carbon was significantly or highly significant correlation with total GRSP in the bulk soil $\left(R^{2}=0.70, P<0.01\right)$, large macroaggregates $\left(R^{2}=0.77, P<0.01\right)$, and microaggregates $\left(R^{2}=0.47, P<0.05\right)$, but easily extractable GRSP had no significant correlation with soil organic carbon in the bulk soil and different aggregates (Fig. 2). 

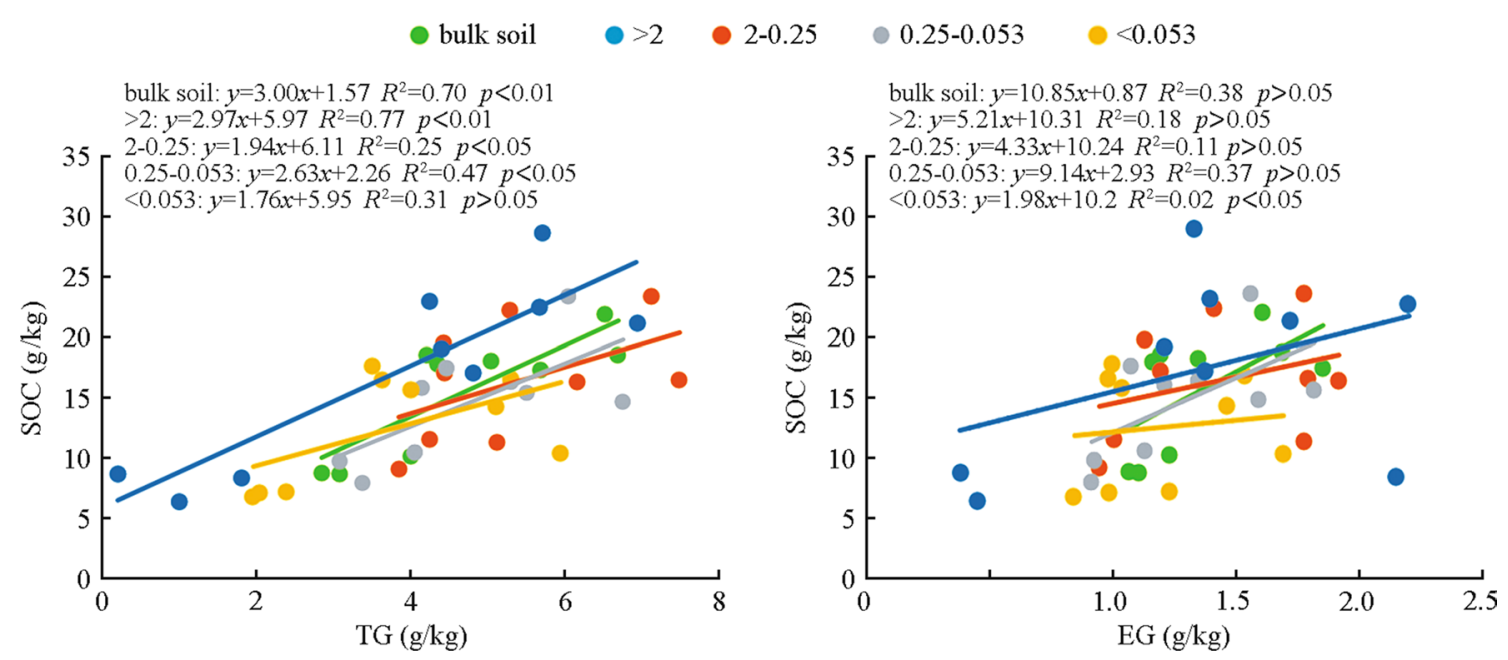

Fig. 2 Regressions between soil organic carbon and glomalin-related soil protein in the bulk soil and different aggregates; EG is easily extractable glomalin-related soil protein; TG is total glomalin-related soil protein; and SOC is soil organic carbon

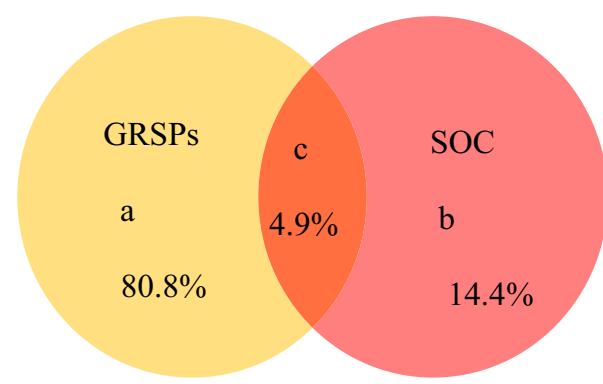

Fig. 3 Glomalin-related soil protein and soil organic carbon as explaining factors for soil aggregate stability variations; GRSP includes the total GRSP and easily extractable GRSP levels in bulk soil and in four aggregates; SOC includes contents in bulk soil and four aggregates

The relative contributions of glomalin-related soil protein and soil organic carbon to soil aggregate stability (mean weight diameter and geometric mean diameter) were determined by RDA variation partitioning analysis (Fig. 3). The contribution of glomalin-related soil protein was the largest factor $(80.8 \%)$, followed by soil organic carbon $(14.4 \%)$, and the remaining $4.9 \%$ was considered to be the interactions between glomalin-related soil protein and soil organic carbon.

To further analyze the influence of variables on soil aggregate stability, conditional term effects were performed in the redundancy analysis ordination (Table 5). Total GRSP of small macroaggregates $(74.6 \%)$ was the most important factor for aggregate stability index followed by the EG/SOC ratio of bulk soil (11.2\%) and the easily extractable GRSP of silt + clay fractions $(2.1 \%)$.
Table 5 Conditional term effects in the redundancy analysis (RDA) ordinations

\begin{tabular}{lcll}
\hline Name & Explains \% & Pseudo-F & $P$ \\
\hline TG content of small macroaggregates & 74.6 & 20.6 & 0.006 \\
EG/SOC of bulk soil & 11.2 & 9.2 & 0.022 \\
SOC content of small macroaggre- & 8.1 & 2.8 & 0.128 \\
$\quad$ gates & & & \\
EG/SOC of microaggregates & 3.4 & 4.9 & 0.074 \\
EG content of silt + clay fractions & 2.1 & 8.9 & 0.038 \\
SOC content of bulk soil mm aggre- & 0.4 & 3.7 & 0.114 \\
$\quad$ gate & & & \\
$\quad$ TG/SOC of silt + clay fractions & 0.2 & 36 & 0.264 \\
EG/SOC of silt + clay fractions & $<0.1$ & $<0.1$ & 1 \\
\hline
\end{tabular}

\section{Discussion}

\section{Effect of organic mulching on soil aggregate distribution and stability}

Soil structure is a key factor influencing soil characteristics and ecological functions related to aggregate stability (He et al. 2020; Ma et al. 2020). Large amounts of macroaggregates and low proportions of silt + clay promote aggregate stability (Dai et al. 2019). Macroaggregates play an important role in maintaining aggregate stability. The higher the proportion of macroaggregates, the stronger the soil aggregate stability (Zhang et al. 2019; Liu et al. 2020). The soil aggregate stability index influenced by soil aggregate distribution is an important index to evaluate the vulnerability of soil degradation and reflects soil structure (Chen et al. 2019; Ma et al. 2020).

In this study, wood chips + wood compost increased the proportion of large and small macroaggregates and 
decreased the ratio of microaggregates and silt + clay fractions, contributing to larger mean weight diameter and geometric mean diameter than wood chips and controls. It has been reported that organic amendment could significantly increase mean weight diameter and geometric mean diameter (Zhang et al. 2014; Zhao et al. 2018). However, wood chips did not increase mean weight diameter and geometric mean diameter compared with the controls in this study, consistent with Fungo et al. (2017) who reported that wood biochar alone did not affect the mean weight diameter in a short-term trial (two years) on a low-fertility ultisol in western Kenya. In this study, wood chips + wood compost was more available to promote aggregate stability in urban forest soil than wood chips alone. The differences in soil aggregate stability could be due to time, application rate, property of organic mulches, and binding agents of different soil aggregates (An et al. 2010; Fungo et al. 2017).

\section{Effects of mulching on soil aggregate binding agents}

Soil aggregate binding agents played a vital role in improving aggregate stability. Binding agents bound microaggregates or silt + clay fractions into macroaggregates to stabilize the soil structure. Organic materials may contribute to the production of more microbial-derived binding agents, leading to higher rates of macroaggregate formation (Liu et al. 2014). Soil organic carbon and glomalin-related soil protein have been reported as important binding agents that contribute to aggregate formation and stability (Zhang et al. 2014; Xiao et al. 2019). In this study, the wood chips + wood compost treatment had a significant impact on glomalinrelated soil protein and less on soil organic carbon. It was also found that the soil organic carbon and glomalin-related soil protein contents in large and small macroaggregates tended to be higher than in microaggregates and silt + clay fractions under the same treatment, consistent with several studies (Liu et al. 2014, 2020; Jing et al. 2021). However, the results of this study were not statistically significant, possibly because soil aggregation and carbon sequestration cannot be completed quickly in a short time (Fungo et al. 2017; He et al. 2020).

Glomalin-related soil protein is produced by arbuscular mycorrhizal fungi and released into the soil with hyphal turnover (Liu et al. 2020). The fungi are crucial to macroaggregate formation which affects the physicochemical characteristics of the soil and represent stabilizing agents in the formation and maintenance of soil structure (Bedini et al. 2009). In the present study, wood chips + wood compost had higher glomalin-related soil protein levels in the bulk soil, and aggregate fractions, and demonstrated that wood compost increased the number of fungi and bind microaggregates or silt + clay fractions together into macroaggregates to maintain the stability of soil aggregates. It was also found that wood chips had the lowest glomalin-related soil protein content in bulk soil and in the four aggregates. Plant residues can accumulate on the soil surface, leading to organic matter accumulation (Zhong et al. 2019) but because litter is not incorporated into the soil as a result of mulching, nutrient cycling and carbon accumulation is challenging (Wang et al. 2014a; Ma et al. 2020). Fresh organic material on mulch could create spots of microbial activity where new soil aggregates are developed, but the decomposition rate of organic material is important for soil aggregation (Zhong et al. 2019; Modak et al. 2020). Generally, the lignin content of wood chips were higher so its rate of degradation was lower than for the wood compost (Wang et al. 2014b; Dietrich et al. 2017, 2019). Two years after application, wood chips had not decomposed on the soil surface, making it difficult to promote microbial activity and increase microbial-derived binding agents. In summary, with a low rate of degradation of wood chips and limited nutrient cycling, wood chips alone did not increase the effectiveness of soil binding agents. Organic amendments might compensate for carbon losses caused by intensive human activities and effectively improve soil organic carbon storage (Xie et al. 2015; Guan et al. 2019). However, wood chips + wood compost did not significantly increase the soil organic carbon in the bulk soil and aggregates after two years, while wood chips significantly decreased soil organic carbon in both in this study. Several studies have indicated that exogenous carbon (i.e., organic mulches, manure, straw, biochar) increase total organic carbon and aggregate-associated carbon contents (Scharenbroch et al. 2014; Kiboi et al. 2020; Somerville et al. 2020). However, other studies have reported the reverse (Franko and Schulz 2021). Soil organic carbon response to organic amendments depends on several factors, including the mulch quality and amount, application time, soil type and characteristics, and climate conditions (An et al. 2010; Fungo et al. 2017; Wang et al. 2017a). In addition, EG/TG (easily extractable/total GRSP) ratios reflect difference in the potential accumulation of glomalin-related soil protein in soils (Liu et al. 2020). TG/SOC (total GRSP/soil organic carbon) ratios and EG/SOC (easily extractable GRSP/soil organic carbon) ratios represent the contribution of glomalin-related soil protein to the total soil organic carbon pool (Wang et al. 2017b, 2020a, 2020b). Wood chips alone significantly increased easily extractable/total GRSP ratios in large macroaggregates and silt + clay fractions, indicating that glomalin-related soil protein accumulation increased. The GRSP/SOC ratios of organic mulching increased, indicating that the contribution of glomalin-related soil protein to the soil organic carbon pool will increase over time with organic mulching. The present study was based on a 2-year trial. Since soil aggregation and carbon sequestration are slow processes, significant effects would not be revealed for some time (Fungo et al. 2017; He et al. 2020). 


\section{Relationships between soil aggregate stability and aggregate binding agents}

The soil aggregate stability index was directly influenced by the aggregate binding agents, indicating that mean weight diameter and geometric mean diameter increased with increasing aggregate binding agents (Zhang et al. 2014). Studies have indicated that the values of mean weight diameter and geometric mean diameter are strongly correlated with soil organic carbon and glomalin-related soil protein, but which is the more important is controversial (Jing et al. 2021). Chen et al. (2019) reported that glomalin-related soil protein is a critical biological binding agent that affects soil aggregate stability and is sensitive to organic amendments, which is similar to the present study. In this study, only glomalin-related soil protein was significantly correlated with mean weight diameter and geometric mean diameter. The contribution of glomalin-related soil protein to soil aggregate stability was $80.8 \%$, while that of soil organic carbon was $14.4 \%$. These results indicate that glomalin-related soil protein was more significant than soil organic carbon. Glomalin-related soil protein, as abundant components of soil organic matter, are generally linked with soil organic carbon (Zhang et al. 2014). In the present study, total GRSP (rather than easily extractable GRSP) had a significantly positive correlation with organic carbon levels in bulk soil and in the different aggregates. This may be because the relationship between soil organic carbon and glomalin-related soil protein is determined by aggregate size (Zhang et al. 2014). Easily extractable GRSP has been recently produced by arbuscular mycorrhizal fungi, believed to be easily decomposed and in low amounts in different soil aggregates, and therefore slightly related to organic carbon in bulk soil and in different aggregates (Jing et al. 2021; Xiao et al. 2019). Redundancy analysis found that the total GRSP of small macroaggregates was the most important factor promoting soil aggregate stability, especially in macroaggregates. The accumulation and redistribution of glomalin-related soil protein in macroaggregates and microaggregates is important for soil aggregate stability (Liu et al. 2020).

Several studies have noted a linear increase of aggregate stability with increasing levels of soil organic carbon (Yilmaz and Sönmez 2017; Wu et al. 2021). However, the present study found a weak relationship, indicating that soil organic carbon as a binding agent could not improve soil aggregate stability in the short term. Zhang et al. (2012) also reported that the direct effect of soil organic carbon on aggregate stability was insignificant, but could improve aggregate stability indirectly through effects on microbial biomass carbon and nitrogen. Therefore, in two years of this study, the carbon sequestration of applying organic amendments in the short term may not be evident. Long- term trials are needed to clarify the effects of wood chips and compost on soil aggregate formation and stability to improve carbon sequestration potential (Fungo et al. 2017; Chen et al. 2018). In addition, this study considered only soil glomalin-related soil protein and soil organic carbon, and not the mechanism of soil aggregate stability. In further research, information on other binding agents (e.g., humus, polysaccharides, fungi, microbial biomass carbon, and nitrogen sources), soil microorganisms, and plant growth would be beneficial (Abiven et al. 2007; Chen et al. 2019).

\section{Implications}

Although there are some limitations on the application of organic mulching in this study, the results can contribute to knowledge on rapid urbanization. In the short term, frequent changes in urban green spaces have affected soil quality and ecosystem functions (Gao et al. 2020; Wang et al. 2020a). In some cities, organic mulching measures have been used to prevent the soil dust storms in winter, and mulches would be removed in warmer weather (Zhang et al. 2017). Therefore, it is necessary to select the most effective way to improve soil quality in the short term. In addition, application of organic mulching need to consider cost (Albiach et al. 2001). Compared with applying wood chips alone, wood chips and wood compost has been more effective and cost-efficient (Scharenbroch et al. 2014). The present study revealed that the dual mulching of wood chips on the upper layer and compost on the under layer was the best way to improve soil quality in urban soil, especially in the short term.

Figure 4 shows the possible mechanisms of organic mulching on soil aggregate stability. Glomalin-related soil protein (GRSP, especially total GRSP) was the most important driver to improve aggregate stability in urban forest soils. Due to human activities, urban soil quality is rapidly declining (Wang et al. 2019a) and rehabilitation of glomalin soil protein is necessary (Wang et al. 2018, 2019b, 2020a). In addition to organic mulching measures, other steps should be taken. Wang et al. (2018) reported that the most important means for improving urban soils were to control $\mathrm{pH}$ and electrical conductivity. In addition, regular loosening of the soil can improve structure and promote nutrient circulation between the soil and the mulch. In the future, the frequent addition of organic mulches on urban soils is necessary (Sun et al. 2021) and soil amendment measures should be adapted to local conditions (Wang et al. 2017c). A program of comprehensive measures could increase glomalin-related soil protein levels and enhance soil aggregate stability in urban forest soils.

\section{Conclusions}

Wood chips + wood compost was the most effective way for improving soil aggregate stability. Glomalin-related soil 


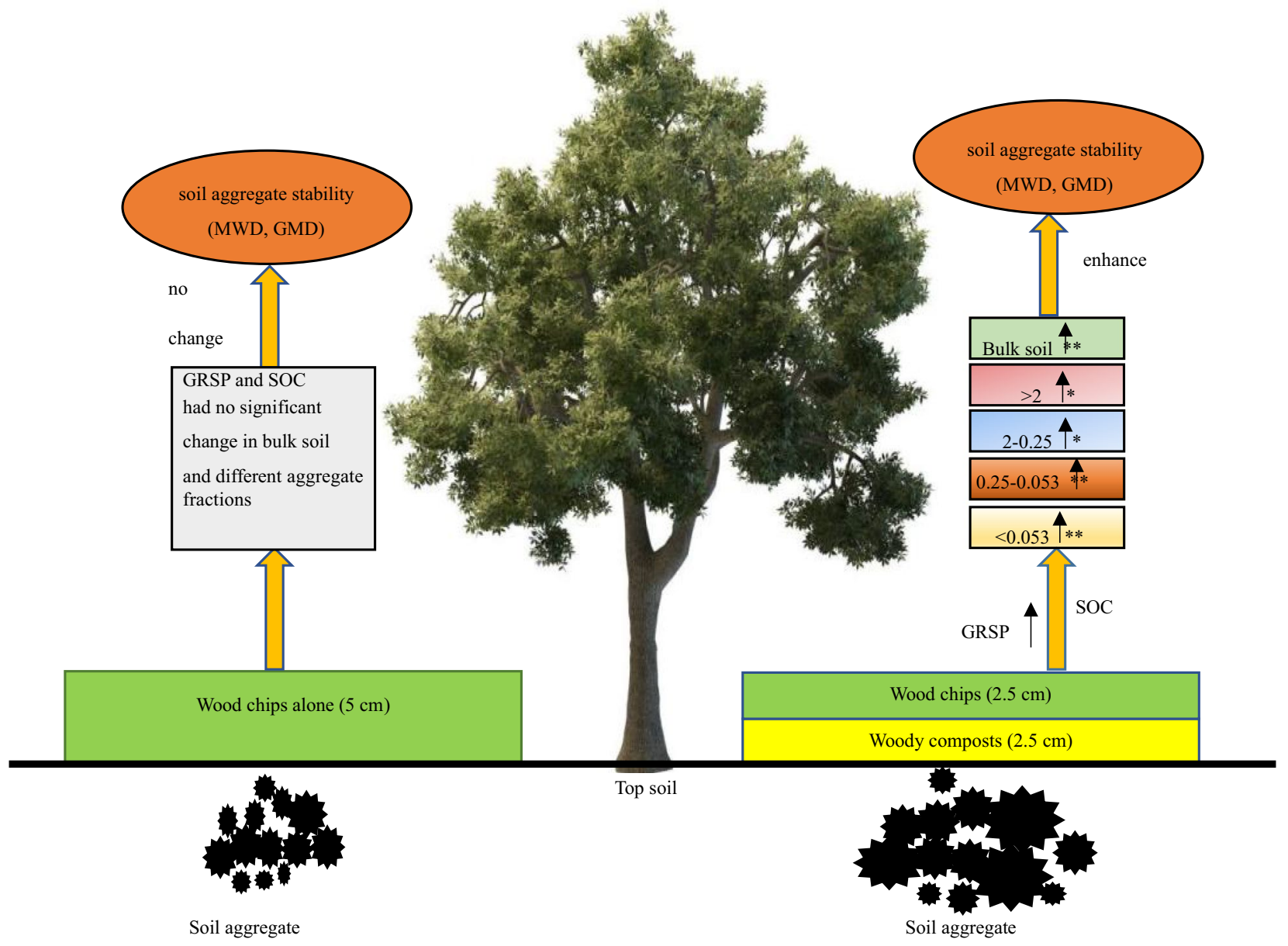

Fig. 4 Schematic diagram showing soil aggregate stability under different amendment treatments; * indicates only total GRSP was significantly increased and **indicates that both total and easily extractable GRSP significantly increased

protein (GRSP, especially total GRSP in small macroaggregates) accumulation was the main factor in promoting soil aggregate stability and improving soil structure. Soil organic carbon had a negligible role in short term organic mulching. In urban forest management, glomalin accumulation in soil should be rehabilitated by amending with wood chips + wood compost.

Open Access This article is licensed under a Creative Commons Attribution 4.0 International License, which permits use, sharing, adaptation, distribution and reproduction in any medium or format, as long as you give appropriate credit to the original author(s) and the source, provide a link to the Creative Commons licence, and indicate if changes were made. The images or other third party material in this article are included in the article's Creative Commons licence, unless indicated otherwise in a credit line to the material. If material is not included in the article's Creative Commons licence and your intended use is not permitted by statutory regulation or exceeds the permitted use, you will need to obtain permission directly from the copyright holder. To view a copy of this licence, visit http://creativecommons.org/licenses/by/4.0/.

\section{References}

Abiven S, Menasseri S, Angers DA, Leterme P (2007) Dynamics of aggregate stability and biological binding agents during decomposition of organic materials. Eur J Soil Sci 58(1):239-247. https:// doi.org/10.1111/j.1365-2389.2006.00833.x

Albiach R, Canet R, Pomares F, Ingelmo F (2001) Organic matter components and aggregate stability after the application of different amendments to a horticultural soil. Biores Technol 76(2):125129. https://doi.org/10.1016/S0960-8524(00)00090-0

An SS, Mentler A, Mayer H, Blum WEH (2010) Soil aggregation, aggregate stability, organic carbon and nitrogen in different soil aggregate fractions under forest and shrub vegetation on the Loess Plateau. China Catena 81(3):226-233. https://doi.org/10.1016/j. catena.2010.04.002

Andruschkewitsch R, Geisseler D, Dultz S, Joergensen RG, Ludwig B (2014) Rate of soil-aggregate formation under different organic matter amendments - a short-term incubation experiment. J Plant Nutr Soil Sci 177(2):297-306. https://doi.org/10.1002/jpln.20120 0628

Bao SD (2000) Soil and agricultural chemistry analysis. China Agriculture Press, Beijing, pp 25-114

Bedini S, Pellegrino E, Avio L, Pellegrini S, Bazzoffi P, Argese E, Giovannetti M (2009) Changes in soil aggregation and 
glomalin-related soil protein content as affected by the arbuscular mycorrhizal fungal species Glomus mosseae and Glomus intraradices. Soil Biol Biochem 41(7):1491-1496. https://doi.org/10. 1016/j.soilbio.2009.04.005

Chen J, Heiling M, Resch C, Mbaye M, Gruber R, Dercon G (2018) Does maize and legume crop residue mulch matter in soil organic carbon sequestration? Agr Ecosyst Environ 265:123-131. https:// doi.org/10.1016/j.agee.2018.06.005

Chen ZJ, Zhou XY, Geng SC, Miao Y, Cao YH, Chen Z, Zhang JH, Han SJ (2019) Interactive effect of nitrogen addition and throughfall reduction decreases soil aggregate stability through reducing biological binding agents. For Ecol Manage 445:13-19. https:// doi.org/10.1016/j.foreco.2019.04.057

Dai HC, Chen YQ, Liu KC, Li ZX, Qian X, Zang HD, Yang XL, Zhao YX, Shen YW, Li ZJ, Sui P (2019) Water-stable aggregates and carbon accumulation in barren sandy soil depend on organic amendment method: a three-year field study. J Clean Prod 212:393-400. https://doi.org/10.1016/j.jclepro.2018.12.013

Dietrich G, Recous S, Pinheiro PL, Weiler DA, Schu AL, Rambo MRL, Giacomini SJ (2019) Gradient of decomposition in sugarcane mulches of various thicknesses. Soil Tillage Res 192:66-75. https://doi.org/10.1016/j.still.2019.04.022

Dietrich G, Sauvadet M, Recous S, Redin M, Pfeifer IC, Garlet CM, Bazzo H, Giacomini SJ (2017) Sugarcane mulch C and N dynamics during decomposition under different rates of trash removal. Agr Ecosyst Environ 243:123-131. https://doi.org/10.1016/j.agee. 2017.04.013

Franko U, Schulz E (2021) Carbon accumulation in a bare fallow Chernozem soil with high carbon input rates. Eur J Soil Sci 72(1):265273. https://doi.org/10.1111/ejss.12937

Fungo B, Lehmann J, Kalbitz K, Thiongo M, Okeyo I, Tenywa M, Neufeldt $\mathrm{H}$ (2017) Aggregate size distribution in a biochar-amended tropical Ultisol under conventional hand-hoe tillage. Soil Tillage Res 165:190-197. https://doi.org/10.1016/j.still.2016.08.012

Gao XS, Huang R, Li J, Wang CQ, Lan T, Li QQ, Deng OP, Tao Q, Zeng M (2020) Temperature induces soil organic carbon mineralization in urban park green spaces, Chengdu, southwestern China: effects of planting years and vegetation types. Urban For Urban Green 54:126761. https://doi.org/10.1016/j.ufug.2020.126761

Guan S, Liu SJ, Liu RY, Zhang JJ, Ren J, Cai HG, Lin XX (2019) Soil organic carbon associated with aggregate-size and density fractions in a Mollisol amended with charred and uncharred maize straw. J Integr Agric 18(7):1496-1507

He LL, Zhao J, Yang SM, Zhou H, Wang SQ, Zhao X, Xing GX (2020) Successive biochar amendment improves soil productivity and aggregate microstructure of a red soil in a five-year wheat-millet rotation pot trial. Geoderma 376:114570. https://doi.org/10. 1016/j.geoderma.2020.114570

Jing H, Meng M, Wang GL, Liu GB (2021) Aggregate binding agents improve soil aggregate stability in Robinia pseudoacacia forests along a climatic gradient on the Loess Plateau. China J Arid Land 13(2):165-174. https://doi.org/10.1007/s40333-021-0002-8

Kiboi MN, Ngetich FK, Fliessbach A, Muriuki A, Mugendi DN (2020) Nutrient release from organic resources in Nitisols of the Central Highlands of Kenya. Geoderma Reg 21:e00287. https://doi.org/ 10.1016/j.geodrs.2020.e00287

Kranz CN, McLaughlin RA, Johnson A, Miller G, Heitman JL (2020) The effects of compost incorporation on soil physical properties in urban soils - A concise review. J Environ Manage 261:110209. https://doi.org/10.1016/j.jenvman.2020.110209

Liu C, Lu M, Cui J, Li B, Fang CM (2014) Effects of straw carbon input on carbon dynamics in agricultural soils: a meta-analysis. Glob Chang Biol 20(5):1366-1381. https://doi.org/10.1111/gcb.12517

Liu HF, Wang XK, Liang CT, Ai ZM, Wu Y, Xu HW, Xue S, Liu GB (2020) Glomalin-related soil protein affects soil aggregation and recovery of soil nutrient following natural revegetation on the
Loess Plateau. Geoderma 357:113921. https://doi.org/10.1016/j. geoderma.2019.113921

Ma L, Wang Q, Shen ST (2020) Response of soil aggregate stability and distribution of organic carbon to alpine grassland degradation in Northwest Sichuan. Geoderma Reg 22:e00309. https://doi.org/ 10.1016/j.geodrs.2020.e00309

Modak K, Biswas DR, Ghosh A, Pramanik P, Das TK, Das S, Kumar S, Krishnan P, Bhattacharyya R (2020) Zero tillage and residue retention impact on soil aggregation and carbon stabilization within aggregates in subtropical India. Soil Tillage Res 202:104649. https://doi.org/10.1016/j.still.2020.104649

Qu BP, Liu YX, Sun XY, Li SY, Wang XY, Xiong KY, Yun BH, Zhang H (2019) Effect of various mulches on soil physico-Chemical properties and tree growth (Sophora japonica) in urban tree pits. PLoS ONE 14(2):e0210777. https://doi.org/10.1371/journal.pone. 0210777

Sax MS, Bassuk N, van Es HV, Rakow D (2017) Long-term remediation of compacted urban soils by physical fracturing and incorporation of compost. Urban For Urban Green 24:149-156. https:// doi.org/10.1016/j.ufug.2017.03.023

Scharenbroch BC, Watson GW (2014) Wood Chips and compost improve soil Quality and Increase Growth of Acer rubrum and Betula nigra in compacted Urban Soil. Arboricul Urban For 40(6):319-331

Somerville PD, Farrell C, May PB, Livesley SJ (2020) Biochar and compost equally improve urban soil physical and biological properties and tree growth, with no added benefit in combination. Sci Total Environ 706:135736. https://doi.org/10.1016/j.scitotenv. 2019.135736

Sun XD, Wang G, Ma QX, Liao JH, Wang D, Guan QW, Jones DL (2021) Organic mulching promotes soil organic carbon accumulation to deep soil layer in an urban plantation forest. For Ecosyst 8(1):2-11. https://doi.org/10.1186/s40663-020-00278-5

Wang BR, Zhao XD, Liu Y, Fang Y, Ma RT, Yu Q, An SS (2019a) Using soil aggregate stability and erodibility to evaluate the sustainability of large-scale afforestation of Robinia pseudoacacia and Caragana korshinskii in the Loess Plateau. For Ecol Manage 450:117491. https://doi.org/10.1016/j.foreco.2019.117491

Wang DW, Yao T, Yang QL, Han HW, Zhang Y, Lu H, Gun SB (2014a) Screening and degradation characterization of efficient and stable cellulose degrading microbial communities. Acta Pratacul Sin 23(2):253-259

Wang HM, Wang WJ, Chen H, Zhang ZH, Mao ZJ, Zu YG (2014b) Temporal changes of soil physic-chemical properties at different soil depths during larch afforestation by multivariate analysis of covariance. Ecol Evol 4(7):1039-1048. https://doi.org/10.1002/ ece3.947

Wang Q, Wang WJ, Zhong ZL, Wang HM, Fu YJ (2020a) Variation in glomalin in soil profiles and its association with climatic conditions, shelterbelt characteristics, and soil properties in poplar shelterbelts of Northeast China. J For Res 31(1):279-290. https:// doi.org/10.1007/s11676-019-00909-w

Wang Q, Wang WJ, He XY, Zhou W, Zhai C, Wang PJ, Tang Z, Wei CH, Zhang B, Xiao L (2019b) Urbanization-induced glomalin changes and their associations with land-use configuration, forest characteristics, and soil properties in Changchun, Northeast China. J Soils Sediments 19(5):2433-2444. https://doi.org/10. 1007/s11368-019-02266-X

Wang Q, Zhang D, Zhou W, He XY, Wang WJ (2020b) Urbanization led to a decline in glomalin-soil-carbon sequestration and responsible factors examination in Changchun, Northeastern China. Urban For Urban Green 48:126506. https://doi.org/10. 1016/j.ufug.2019.126506

Wang WJ, Lu JL, Du HJ, Wei CH, Wang HM, Fu YJ, He XY (2017a) Ranking thirteen tree species based on their impact on soil physiochemical properties, soil fertility, and carbon sequestration in 
Northeastern China. For Ecol Manage 404:214-229. https://doi. org/10.1016/j.foreco.2017.08.047

Wang WJ, Wang Q, Zhou W, Xiao L, Wang HM, He XY (2018) Glomalin changes in urban-rural gradients and their possible associations with forest characteristics and soil properties in Harbin City, Northeastern China. J Environ Manage 224:225-234. https://doi. org/10.1016/j.jenvman.2018.07.047

Wang WJ, Zhang B, Zhou W, Lv HL, Xiao L, Wang HY, Du HJ, He XY (2019c) The effect of urbanization gradients and forest types on microclimatic regulation by trees, in association with climate, tree sizes and species compositions in Harbin city, northeastern China. Urban Ecosyst 22(2):367-384. https://doi.org/10.1007/ s11252-019-0823-9

Wang WJ, Zhong ZL, Wang Q, Wang HM, Fu YJ (2017b) Glomalin contributed more to carbon, nutrients in deeper soils, and differently associated with climates and soil properties in vertical profiles. Sci Rep 7:13003. https://doi.org/10.1038/ s41598-017-12731-7

Wang WJ, Zhou W, Wang HM, Ji CP, Han SJ (2017c) Organic carbon and nitrogen dynamics in different soil fractions between broadleaved Korean pine forests and aspen-birch forests in northeastern China. J Soils Sedim 17(9):2257-2273. https://doi.org/10.1007/ s11368-016-1438-x

Wei C, Wang Q, Ren ML, Pei ZX, Lu JL, Wang HM, Wang WJ (2020) Soil aggregation accounts for the mineral soil organic carbon and nitrogen accrual in broadleaved forests as compared to that of coniferous forests in Northeast China: cross-sites and multiple species comparisons. Land Degrad Dev 32(1):296-309. https:// doi.org/10.1002/ldr.3725

Wright SF, Upadhyaya A, Buyer JS (1998) Comparison of N-linked oligosaccharides of glomalin from arbuscular mycorrhizal fungi and soils by capillary electrophoresis. Soil Biol Biochem 30(13):1853-1857. https://doi.org/10.1016/S0038-0717(98) 00047-9

Wu QC, Jiang XH, Lu QW, Li JB, Chen JL (2021) Changes in soil organic carbon and aggregate stability following a chronosequence of Liriodendron chinense plantations. J For Res 32(1):355-362. https://doi.org/10.1007/s11676-020-01110-0

Xiao L, Zhang Y, Li P, Xu GC, Shi P, Zhang Y (2019) Effects of freeze-thaw cycles on aggregate-associated organic carbon and glomalin-related soil protein in natural-succession grassland and Chinese pine forest on the Loess Plateau. Geoderma 334:1-8. https://doi.org/10.1016/j.geoderma.2018.07.043

Xie HT, Li JW, Zhang B, Wang LF, Wang JK, He HB, Zhang XD (2015) Long-term manure amendments reduced soil aggregate stability via redistribution of the glomalin-related soil protein in macroaggregates. Sci Rep 5:14687. https://doi.org/10.1038/srep1 4687
Yang J, McBride J, Zhou JX, Sun ZY (2005) The urban forest in Beijing and its role in air pollution reduction. Urban For Urban Green 3(2):65-78. https://doi.org/10.1016/j.ufug.2004.09.001

Yilmaz E, Sönmez M (2017) The role of organic/bio-fertilizer amendment on aggregate stability and organic carbon content in different aggregate scales. Soil Tillage Res 168:118-124. https://doi.org/ 10.1016/j.still.2017.01.003

Zhang H, Wang XY, Zhang JD, Qu BP, Wang XP, Gong XQ, Zhang L, Sun XY (2017) Investigation and distributions of the bare lands among gardens and greenbelts in winter within the 5th Ring of Beijing. Sci Soil Water Conserv 15(2):79-84

Zhang SX, Li Q, Zhang XP, Wei K, Chen LJ, Liang WJ (2012) Effects of conservation tillage on soil aggregation and aggregate binding agents in black soil of Northeast China. Soil Tillage Res 124:196202. https://doi.org/10.1016/j.still.2012.06.007

Zhang XK, Wu X, Zhang SX, Xing YH, Wang R, Liang WJ (2014) Organic amendment effects on aggregate-associated organic $\mathrm{C}$, microbial biomass $\mathrm{C}$ and glomalin in agricultural soils. CATENA 123:188-194. https://doi.org/10.1016/j.catena.2014.08.011

Zhang Y, Li P, Liu XJ, Xiao L, Shi P, Zhao BH (2019) Effects of farmland conversion on the stoichiometry of carbon, nitrogen, and phosphorus in soil aggregates on the Loess Plateau of China. Geoderma 351:188-196. https://doi.org/10.1016/j.geoderma. 2019.05.037

Zhao HL, Shar AG, Li S, Chen YL, Shi JL, Zhang XY, Tian XH (2018) Effect of straw return mode on soil aggregation and aggregate carbon content in an annual maize-wheat double cropping system. Soil Tillage Res 175:178-186. https://doi.org/10.1016/j.still.2017. 09.012

Zhong ZK, Han XH, Xu YD, Zhang W, Fu SY, Liu WC, Ren CJ, Yang GH, Ren GX (2019) Effects of land use change on organic carbon dynamics associated with soil aggregate fractions on the Loess Plateau China. Land Degrad Develop 30(9):1070-1082. https:// doi.org/10.1002/ldr.3294

Zhou W, Wang WJ, He XY, Zhang B, Xiao L, Wang Q, Lv HL, Wei CH (2018) Soil fertility and spatial variability of urban green land in Harbin. Scientia Silvae Sinicae 54(9):9-17

Zhou W, Wang WJ, Zhang B, Xiao L, Lv HL, He XY (2017) Soil fertility evaluation for urban forests and green spaces in Changchun City. Acta Ecol Sin 37(4):1211-1220

Publisher's Note Springer Nature remains neutral with regard to jurisdictional claims in published maps and institutional affiliations. 